Digital Press Life Sciences

Antioxidant Activity, Fiber, Acidity ( $\mathrm{pH})$, and Population of Lactic Acid Bacteria in Green Juice as Functional Beverages

Ni Wayan Nursini, Komang Lina Venti Santiani and I Gusti Ayu Wita Kusumawati

10th Asian Conference of Lactic Acid Bacteria

I Nengah Sujaya, Endang S. Rahayu, Tyas Utami (eds) 


\title{
Antioxidant Activity, Fiber, Acidity (pH), and Population of Lactic Acid Bacteria in Green Juice as Functional Beverages
}

\author{
Ni Wayan Nursini*, Komang Lina Venti Santiani, and I Gusti Ayu Wita Kusumawati \\ Faculty of Health Science and Technology, Dhyana Pura University \\ *e-mail: nursini_2811@yahoo.com
}

\begin{abstract}
Bok choy (Brassica rapa L) is a vegetable group of Brassicaceae which still a family with Chinese vegetables. It contains phytochemical substances such as carotenoids, $\beta$-carotene, and glucosinolates which are a source of antioxidant. Bok choy can be processed into juice. The purpose of this research is to determine the content of the antioxidant activity, fiber, acidity $(\mathrm{pH})$ and population of lactic acid bacteria in each formulation. The other ingredients added in making this green juice are yogurt and honey made into 5 formulations. The analysis of this research was the analysis of antioxidant activity content using DPPH method (2.2, -diphenyl-1- picrylhydrazyl), crude fiber contents analysis using gravimetric method, $\mathrm{pH}$ analysis using $\mathrm{pH}$ meter and analysis of lactic acid bacteria using spread plate method. The result obtained is the highest content of the antioxidant activity was found in formulation 5 consist of $30 \mathrm{~g}$ yogurt, $15 \mathrm{~g}$ honey and $50 \mathrm{~g}$ bok choy with $35,198 \pm 0,057 \%$. The content of crude fiber ranged from $(0,447 \pm 0,046) \mathrm{g}$ to $(0,507 \pm 0,058) \mathrm{g}$. The highest of acidity $(\mathrm{pH})$ is in formulation 1 which consists of $10 \mathrm{~g}$ of yogurt, $15 \mathrm{~g}$ of honey and $50 \mathrm{~g}$ of bok choy at 5,50 $\pm 0,040$. The highest population content of lactic acid bacteria in formulation 5 consists of $30 \mathrm{~g}$ yogurt, $15 \mathrm{~g}$ honey and $50 \mathrm{~g}$ bok choy at $2,8 \mathrm{x} 106 \mathrm{cfu} / \mathrm{mL}$. Therefore, green juice can be used as functional drinks.
\end{abstract}

\section{Keywords}

bok choy, green juice, antioxidant activity, crude fiber, lactic acid bacteria

\section{Introduction}

In Indonesia, consumption of vegetables and fruit and its processing is still low. Consumption of fruits and vegetables that do not meet the recommendation gives effects on the supply of vitamins, minerals, and fiber needed by the body [1]. The consumption rate of vegetables and fruit in Indonesia is below the recommended 95\% per capita per day, the minimum requirement is $120 \mathrm{kcal}$ per capita per day [2]. The research from the Ministry of Health [3] states that 93.5\% of Indonesia's population aged > 10 years consume vegetables and fruit under the recommendation. WHO recommends 400-600 grams consumption of vegetables and fruit per person per day consisting of 250 grams of vegetables and 150 grams of fruit for a healthy life [4].

Factors affecting the lack of vegetable and fruit intake include low economic factors, lack of availability of vegetables and fruits [5], environmental problems, delays in the introduction of vegetables and fruit, ways of processing and preparing food [6]. Some effects due to lack of vegetables and fruit such as decreased immunity and immune system, digestive tract disorders, disorders of the eye and high blood pressure $[7,8]$.

Vegetables can be processed by sautéing, boiling and making it in the form of soup, and juice. Juice can be made from one or a mixture of various types of fruit or vegetables. Some studies use vegetables and fruit for juice making such as broccoli juice as an anti-cancer and antioxidant therapy [9], red guava juice [10], watermelon juice as a source of phenolate and antioxidant activity [11], and cucumber juice for lowering blood pressure [12]. Bok choy vegetable is one of the vegetables that can be made in the form of juice as a functional drink. Functional properties in functional foods are due to the presence of bioactive components found in ingredients such as food fiber and antioxidants [13]. Functional beverages are complemented by tertiary functions such as probiotics, increasing vitamin and mineral intake [14].

In Indonesia, bok choy vegetables are processed into various types of dishes, besides being easily cultivated they also have relatively cheap prices. The leaf from bok choy vegetable is a source of 
carotenoids, $\beta$-carotene, glucosinolate, iron, and calcium $[15,16,17]$. Making green juice from bok choy vegetables alone results in a bland taste with a distinctive vegetable flavor. Hence, the formulation is made with the addition of yogurt and honey. Antioxidant activity is influenced by total phenolic and flavonoid compounds $[18,19,20]$. Yogurt is a milk product fermented by lactic acid bacteria (LAB), namely Streptococcus thermophilus and Lactobacillus bulgarius [21]. Probiotics in inhibiting pathogenic organisms by competing to obtain a number of food ingredients for fermentation. These foods are needed so that probiotics can develop properly. Food that supports the development of probiotics in the digestive tract is called prebiotics. Prebiotics consist of food ingredients which generally contain a lot of fiber. Probiotics that produce lactic acid from the lactobacillus species, produce cellulase enzymes that aid the digestion process [22].

Honey is a liquid that is produced by bees from plant flower extracts that are collected and stored in the hive for maturation [23] honey has active components that function as antioxidants namely vitamin $\mathrm{C}$, vitamin A, vitamin E, Flavonoids and $\beta$-carotene $[24,25,23]$. So that research was conducted to find out how the antioxidant activity, fiber, acidity $(\mathrm{pH})$ and lactic acid bacteria (LAB) population in green juice formulations as functional drinks.

\section{Materials and Methods}

\subsection{Preparation of Green Juice Samples}

The sample used was a green juice, with basic ingredients of bok choy (Brassica rapa L), yogurt and honey. Bok choy vegetables were washed thoroughly, cut and then inserted into a blender along with yogurt, honey and water. All ingredients were blended until it dissolved and homogeneous which resulted in juice. The juice that has been blended based on a predetermined formulation as described in Table 1 was then analyzed for its antioxidant activity, crude fiber content, acidity (pH) and LAB population.

Table 1 Green Juice Formulation

\begin{tabular}{lccccc}
\hline \multicolumn{1}{c}{ Materials } & \multicolumn{5}{c}{ Formulation } \\
\cline { 2 - 6 } & F1 & F2 & F3 & F4 & F5 \\
\hline Bok choy (g) & 50 & 50 & 50 & 50 & 50 \\
Yogurt (g) & 10 & 15 & 20 & 25 & 30 \\
Honey (mL) & 15 & 15 & 15 & 15 & 15 \\
Water (mL) & 200 & 200 & 200 & 200 & 200 \\
\hline
\end{tabular}

\subsection{Antioxidant Activity of Green Juice Samples}

Antioxidant activity test used the DPPH (1,1-diphenyl-2-picrylhydrazyl) method (Merck) [26,27]. One mL of standard solution or sample was added $3 \mathrm{~mL}$ of DPPH solution $(0.004 \%$ in methanol). Then, the solution was left out for about 30 minutes in darkroom temperature during the incubation of DPPH radicals reacting with antioxidant compounds contained in the sample changes in color from purple to fade. Furthermore, the absorbance was measured using a UV-Vis spectrophotometer (Shimadzu UV-1601) with a wavelength of $517 \mathrm{~nm}$. The fading of the colors produced the higher the antioxidant activity.

\subsection{Crude Fiber of Green Juice Samples}

Crude fiber test with modification as suggested by Kusumawati and Yogeswara [28] was conducted in this study. A sample of 10 grams was weighed using a Gewinn Scale and accommodated into an Erlenmeyer flask (Iwaki Pyrex), then added $50 \mathrm{~mL}$ of $\mathrm{H}_{2} \mathrm{SO}_{4}-0.255 \mathrm{~N}$ and closed with back cooling. Afterward, it was boiled for 1 hour, the suspension was filtered, and the residue left in the Erlenmeyer was washed with distilled water through filter paper until the washing water was not acidic. The following steps were then performed by transferring back the residue on filter paper quantitatively into the Erlenmeyer using a spatula. The remainder was washed with $50 \mathrm{~mL}$ of $\mathrm{NaOH}-0.255 \mathrm{~N}$ (Merck) until the residue entered the Erlenmeyer. Then it was simmered for approximately 1 hour. The sample was filtered using a filter paper (Whatman 42) which has been known to weigh after drying while washing successively with boiling distilled water solution and alcohol each of $15 \mathrm{~mL}$ each. Filter paper and its contents were dried at $70^{\circ} \mathrm{C}$ to 
constant weight for 1 hour. Then, it was cooled again in a desiccator and weighed by reducing the weight of filter paper.

\section{4 pH of Green Juice Samples}

Acidity test by measuring $\mathrm{pH}$ [29]. The pH meter (Hanna) is turned on and calibrated with a buffer of pH 4 and $\mathrm{pH}$ 7. Samples were taken as much as $30 \mathrm{~mL}$ and placed in plastic cups. Then the $\mathrm{pH}$ of the sample is measured for 30 seconds. Every time another $\mathrm{pH}$ sample is measured, the $\mathrm{pH}$ meter is cleaned with distilled water and dried with a tissue paper.

\subsection{Total Lactic Acid Bacteria of Green Juice Samples}

Green juice samples were put into $0.1 \%$ peptone water (Oxoid) and homogeneous using vortex (Labinco). Homogeneous samples were made into a dilution series in $0.1 \%$ peptone water. Then they were spread on MRS agar media (Oxoid) and incubated, for 48 hours at $37^{\circ} \mathrm{C}$ to see the population of lactic acid bacteria [30].

\subsection{Statistical Analysis}

Data were analyzed using a one-way analysis of variance (ANOVA) test and if the data obtained showed significantly different then the Tukey method was tested. Data were analyzed using SPSS ver.22 (with statistical significance at $p<0.05$ ).

\section{Results and Discussion}

The results analysis of green juice as a functional beverage can be seen in Table 2 .

Table 2 Results analysis of green juice as a functional beverage

\begin{tabular}{|c|c|c|c|c|}
\hline $\begin{array}{l}\text { Green juice } \\
\text { formulation }\end{array}$ & $\begin{array}{c}\text { Antioxidant activity } \\
(\%)\end{array}$ & Fiber crude (g) & $\mathrm{pH}$ & LAB population $(\mathrm{cfu} / \mathrm{mL})$ \\
\hline F1 & $22.395 \pm 0.051^{\mathrm{a}}$ & $0.490 \pm 0.519^{a}$ & $5.50 \pm 0.040^{\mathrm{e}}$ & $4.60 \times 10^{5} \pm 0.624^{a}$ \\
\hline $\mathrm{F} 2$ & $26.224 \pm 0.102^{\mathrm{ab}}$ & $0.503 \pm 0.103^{a}$ & $5.26 \pm 0.011^{\mathrm{d}}$ & $6.93 \times 10^{5} \pm 1.800^{a}$ \\
\hline F3 & $24.009 \pm 0.187 \mathrm{a}$ & $0.493 \pm 0.187^{\mathrm{a}}$ & $5.03 \pm 0.005^{c}$ & $8.26 \times 10^{5} \pm 0.808^{a}$ \\
\hline F4 & $31.002 \pm 0.046^{\mathrm{bc}}$ & $0.447 \pm 0.046^{\mathrm{a}}$ & $4.92 \pm 0.015^{b}$ & $1.10 \times 10^{5} \pm 5.408^{a}$ \\
\hline F5 & $35.198 \pm 0.057 c$ & $0.507 \pm 0.058^{a}$ & $4.74 \pm .0115^{\mathrm{a}}$ & $2.80 \times 10^{6} \pm 2.645^{b}$ \\
\hline
\end{tabular}

Note: Data are expressed as mean \pm SD from triplicate experiments. Different letters in the column of each group are significantly different $(\mathrm{P}<0.05)$.

\subsection{Antioxidant Activity of Green Juice Samples}

The results of this study showed the antioxidant activity of green juice ranged from $22.395 \pm 0.051 \%$ to $35.198 \pm 0.057 \%$. The highest antioxidant activity was found in formulation 5 (F5) with the addition of 30 grams of yogurt, namely $35.198 \pm 0.057 \%$. Analysis of the content of antioxidant activity in vegetables bok choy without the addition of other ingredients with 50 grams bok choy concentration obtained antioxidant activity content of $56.818 \%$, honey $49.650 \%$, and yogurt $42.307 \%$. The process in making each formulation may damage the structure of the hydroxyl position in the flavonoids in vegetables so that it can reduce antioxidant activity [31]. Juice processing can reduce this antioxidant activity due to the degradation of bioactive compounds. The decrease in vitamin $\mathrm{C}$ content and antioxidant activity due to fresh broccoli undergoes several processing processes such as cutting, washing, and excessive destruction can cause antioxidant activity on the material to be easily damaged oxidized and trigger the activity of enzymes such as peroxidase, ascorbic acid oxidase and phenolase [32]. The type of process in making green juice can significantly affect the antioxidant content, especially phenolic content. Polyphenol compounds containing various phenolic hydroxyl groups are responsible for antioxidant capacity and free radicals [33]. The effects of processing by pasteurization and without pasteurization affect the antioxidant activity, processing by pasteurization can reduce antioxidant activity compared to without pasteurization [34]. Yulita et al. states 
[35] that the small amount of antioxidants in noni juice syrup is caused by the addition of water, because the higher the dilution of the existing antioxidant compounds, the less.

\subsection{Fiber Crud of Green Juice Samples}

Crude fiber is a part of the water-insoluble fiber that cannot be hydrolyzed with acid-base. The content of crude fiber in green juice as a functional drink ranges from $0.447 \pm 0.046 \mathrm{~g}$ to $0.507 \pm 0.058 \mathrm{~g}$. The content of pure bok choy fiber without the addition of other ingredients has a fiber content of $0.052 \mathrm{~g}$, honey has a fiber content of $0.067 \mathrm{~g}$, and yogurt has a crude fiber content of $0.034 \mathrm{~g}$. The results of the analysis of crude fiber content in green juice as a functional drink can be seen in Table 2.

The fiber content in the formulation is higher than the fiber in the base material. The increased crude fiber content with increased yogurt used is thought to be due to increased biomass production. Bacterial cell walls are a source of fiber so that the fiber content of the product increases [36]. Bacteria that are classified as lactobacillus can produce cellulase enzymes that can help digest crude fiber, bacteria from lactobacillus produce glucanase enzymes that are able to break down beta-glucans into glucose, glucanase are part of hemicellulose in which hemicellulose enzymes can break down hemicellulose. The processing process can increase crude fiber. The crude fiber content found in the skin of tomatoes is a water-insoluble fiber such as cellulose and hemicellulose so that when blended it does not cause the fiber to dissolve [37]. Crude fiber is a collection of indigestible fibers, fiber components consisting of cellulose, hemicellulose, and lignin [38]. Fiber has prebiotic compounds that are good for digestion usually from fruits and vegetables [39]. Prebiotics are generally carbohydrates that cannot be digested and absorbed, usually in the form of oligosaccharides and food fiber, which are useful for stimulating the growth of beneficial bacteria in the normal flora of small intestines [40].

\section{3 pH of Green Juice Samples}

The results of this study indicate that the average $\mathrm{pH}$ value of green juice as a functional beverage ranges between 4.75-5.50. The highest $\mathrm{pH}$ value is in formulation 1 (F1) with the addition of yogurt as much as 10 grams with a pH of $5.50 \pm 0.040$ while the lowest $\mathrm{pH}$ is found in the formulation (F5) with the addition of yogurt as much as 30 grams with a pH of $4.74 \pm 0.0115$. The results of the analysis of the acidity (pH) of green juice as a functional beverage can be seen in Table 2 .

The acidity $(\mathrm{pH})$ decreases with the addition of different amounts of yogurt in each formulation, $10 \mathrm{~g}$, $15 \mathrm{~g}, 20 \mathrm{~g}, 25 \mathrm{~g}$, and $30 \mathrm{~g}$. An increase in acidity or a decrease in pH will help inhibit pathogenic bacteria (42). Plain yogurt used has a pH of 4.28 and kapok honey has a pH of 3.56. The $\mathrm{pH}$ value of yogurt ranges from $3.8-4.6$. Thus, the $\mathrm{pH}$ of plain yogurt is still according to established standards. The decrease in $\mathrm{pH}$ is also influenced by the acidity of honey [41]. Honey is an acidic liquid with a $\mathrm{pH}$ of 3.9, thus the addition of honey can affect the decrease in $\mathrm{pH}$ [42]. The acidity of the $\mathrm{pH}$ is determined by the amount of yogurt added to each formulation.

\subsection{Total Lactic Acid Bacteria (BAL)}

The viability of lactic acid bacteria in juices varies between formulations ranging from $4.6 \times 10^{5} \mathrm{cfu} / \mathrm{mL}$ to $2.8 \times 10^{6} \mathrm{cfu} / \mathrm{mL}$. The highest viability of lactic acid bacteria reached $2.8 \times 10^{6} \mathrm{cfu} / \mathrm{mL}$ with a $\mathrm{pH}$ of 4.74 which was obtained in formulation 5 (F5) with the addition of 30 grams of yogurt while, the lowest amount of lactic acid bacteria was $4.6 \times 10^{5} \mathrm{cfu} / \mathrm{mL}$ with a $\mathrm{pH}$ of 5.50, obtained in formulation (F1) with the addition of yogurt as much as 10 grams. The results of the population analysis of lactic acid bacteria in green juice as functional drinks can be seen in Table 2 .

Table 2 shows that the population of lactic acid bacteria found in green juice has increased in formulation 5 , this is due to the addition of different yogurt in each formulation. The higher the formulation the more yogurt is added as well as the $\mathrm{pH}$, the higher the yogurt content added the lower the $\mathrm{pH}$ of each formulation [43]. Lactic acid causes a decrease in the $\mathrm{pH}$ value, the value is determined due to the presence of $\mathrm{H}^{+}$ions so that the $\mathrm{pH}$ decreases [44].

Plain yogurt used in the manufacture of juice contains lactic acid bacteria which is $8.7 \times 10^{6} \mathrm{cfu} / \mathrm{mL}$. Yogurt which is used as a control is higher than the formulation, this is because the content in different samples containing different nutrients is one of the factors that influence cell growth [45]. Yogurt by giving green grass jelly extract produces lactic acid bacteria that are $1,05 \times 10^{6} \mathrm{cfu} / \mathrm{mL}$ [46]. Yogurt with the addition of honey pineapple has a total amount of lactic acid bacteria that is $1.59 \times 10^{4} \mathrm{cfu} / \mathrm{mL}$, lactic acid bacteria can grow maximum in the growth medium depending on the available nutrient content that can be directly used for growth [47]. Both S. thermophilus and L. bulgaricus can grow together in a symbiotic 
mutualism. Streptococcus thermophilus grows because it is stimulated by the presence of lysine and histidine from protein degradation by L. bulgaricus while L. bulgaricus grows rapidly after S. thermophilus reaches stationary phase. The amount of lactic acid bacteria that must be contained in a probiotic food product in order to provide health effects for the human digestive tract is $10^{7}$ cells $/ \mathrm{mL}$ [46].

\section{Conclusions}

From the research results obtained, it can be concluded that formulation 5 consisting of $30 \mathrm{~g}$ yogurt, $15 \mathrm{~g}$ honey and $50 \mathrm{~g}$ bok choy has the highest antioxidant activity that is equal to $35,198 \pm 0.057$ and population of lactic acid bacteria $2.8 \times 10^{6} \mathrm{cfu} / \mathrm{mL}$, fiber content roughly $0.507 \pm 0.058$ and the acidity value is $4.74 \pm$ .0115 .

\section{References}

1. Hermina, \& Prihatini, S.: Gambaran Konsumsi Sayur dan Buah Penduduk Indonesia dalam Konteks Gizi Seimbang: Analisis Lanjut Survei Konsumsi Makanan Individu (SKMI). Buletin Penelitian Kesehatan. 44 (3), 205-218 (2014).

2. Ichsan, B., Wibowo, B.H., \& Sidiq, M.N.: Penyuluhan Pentingnya Sayur bagi Anak- anak di TK Aisyyah Kwandungan, Trowangsa, Malangjiwan Colomadu Karanganyar, Jawa Tengah. Jurnal Keperawatan. 2(2), 22- 23 (2015).

3. Riset Kesehatan Dasar. Jakarta: Badan Penelitian dan Pengembangan Kesehatan. (2010).

4. Kementrian Kesehatan (Kemenkes) Republik Indonesia. Riset penelitian. (2014)

5. Hasana, A. N.: Gambaran Perilaku Ibu dalam Penyediaan Sayur Keluarga di Kelurahan Pasir Bidang Kecamatan Sarudik Kabupaten Tapanuli Tengah. Skripsi Sarjana. Medan, Universitas Sumatra Utara. (2012)

6. Yulandari, S.: Hubungan Tingkat Pengetahuan Dengan Tingkat konsumsi Buah dan Sayur Pada Ana Kelas IV-V SD Pertiwi 3. Skripsi Sarjana. Fakultas Ilmu Kesehatan (2013).

7. Dejesetya, M. P.: Pola Konsumsi Sayur dan Buah Anak Usia 4-6 Tahun Pada Masyarakat Pesisir Desa Randusanga Kulon Brebes. Skripsi Sarjana. Fakultas Ilmu Pendidikan Universitas Negeri Malang. (2016).

8. Yuliana, R., Rahmawati, S. I., Novidahlia, N.: Minuman Sirup Limbah Sari Mengkudu (Morinda citrifolia L.). Jurnal Pertanian. 8(2), 121-129 (2017).

9. Setyoadi, Yulian, W. U., Yuliatun, L., \& Lowita, F.: Jus Brokoli Menurunkan Kadar Low Density Lipoprotein darah Pada Tikus Model diabetes Melitus. Jurnal Kedoteran Brawijaya. 28(1), 26-29 (2014).

10. Rusdi P.H.N., Oenzil F., Chundrayetti. 2018. Pengaruh Pemberian Jus Jambu Biji Merah (Psidium Guajava L) Terhadap Kadar Homoglobin dan Ferritin Serum Penderita Anemia Remaja Putri. Jurnal fk Unand, 7 (1) p. 74-79

11. Ismayanti, Bahri S., Nurhaeni.: Kajian Kadar Fenolat dan Aktivitas Antiokidan Jus Kulit Buah Semangka. Jurnal of natural science. 2(3), 100-110 (2013).

12. Kharisna, D., Dewi, W. N., \& Lestari, W.: Efektivitas Konsumsi Jus Mentimun Terhadap Penurunan Tekanan Darah Pada Pasien Hipertensi. Jurnal Ners Indonesia. 2(2), 124-131 (2012).

13. Kamsina, Nova, I. T. A., \& Firdausni.: Pengaruh Perbandingan Sari Buah dan Gula Terhadap Mutu Minuman Fungsional Labu Kuning. Balai Riset dan Standardisasi Industri Padang. 113-122 (2015).

14. Rezawidya. 2011. Konsep minuman fungsional sebagai solusi cerdas membentuk masyarakat modern yang sehat.

15. Hanson, P., Yang, R., Chang, L.C., Ledesma, L., \& Ledesma, D.: Contents of Carotenoids, Ascorbic Acid, Minerals and Total Glucosinolates in Leafy Brassica Pakchoi (Brassica Rapa L. Chinensis) as affected by Season and Variety. Society of Chemical Industry. 89, 906-914 (2008).

16. Yeni, F., \& Irawati.: Hubungan Fungsi Perawatan Keluarga Dengan Kadar Kolesterol Pasien Hiperkolesterolemia di Wilayah Kerja Puskesmas Andalas Padang Tahun 2013. Ners Jurnal Keperawatan. 9(1), 43-57 (2013).

17. Susilorini, T. E., \& Sawitri, M. E.: Produk Olahan Susu. Penebar Swadaya. Depok. Jawa Barat. (2009). 
18. Beretta, G., Granata, P., Ferrero, M., Orioli, M., Facino, R. M.: Standardization of Antioxidant Properties of Honey by a Combination of Spectrophotometric / Fluorimetric Assays and Chemometrics. Anal. Chim. Acta. 533, 185-191 (2005).

19. Holderna, K. E., \& Kedzia, B.: Research on an Antioxidant Capacity of Honey. Acta Agrobot. 59, 265-269 (2006).

20. Nayik G. A., \& Nanda, V.: Physico- Chemical, Enzymatic, Mineral and colour Characterization of Three Different Varieties of Honeys from Kashmir Valley of India with a Multivariate Approach. Journal Nutrition Soi. 65(2), 101-108 (2015).

21. Karinawatie, S., Kusnadi, J., \& Martati, E.: Efektivitas Konsentrat Protein Whey dan Dekstrin Untuk Mempertahankan Viabilitas Bakteri Asam Laktat Dalam Starter Kering Beku Yogurt. Jurnal Teknologi Pertanian. 9(2), 121-130 (2008).

22. Agus, N. A.: Isolasi dan Karakteristik Bakteri Asam Laktat Asal Saluran Pencernaan Broiler Umur Tiga Hari. Skripsi S1. Fakultas Sains dan Teknologi Universitas Islam Negeri Alauddin. (2016).

23. Widowati E., Adriani, Ir.MAM. MS., Kusumaningrum, P.: Kajian Total Bakteri Probiotik dan Aktivitas Antioksidan Yogurt Tempe Dengan Variasi Substrat. Jurnal Teknologi Hasil Pertanian. 5(1), 18-31 (2011).

24. Latumahina, G. J., Kakisina, P., \& Moniharapon, M.: Peran Madu Sebagai Antioksidan dalam Mencegah Kerusakan Pankreas Mencit (Mus Musculus) Terpapar Asap Rokok Kretek Molucca. Jurnal Kedokteran dan Kesehatan. 4(1), 106-116 (2011).

25. Lubis, Z.: Hidup Sehat Dengan Makanan Kaya Serat. Bogor: IPB Press. 6-9 (2010).

26. Hanani, E., Mun'im, A., \& Sekarini, R.: Identifikasi Senyawa Antioksidan Dalam Spons Callyspongia sp dari Kepulauan Seribu. Majalah Ilmu Kefarmasian. 2(3): 127-133 (2005).

27. Kusumawati, I. G. A. W., \& Yogeswara, I. B. A.: Antioxidant and Antibacterial Capacity of Loloh Sembung (Blumea Balsamifera) Based on Extraction Method. Tred Med Journal. 21(3), 143-148 (2016).

28. Sudarmadji, S., Haryono, B., Suhardi.: Analisis Bahan Makanan dan Pertanian. Liberty Yogyakarta bekerjasama dengan pusat antar Universitas pangan dan Gizi Universitas Gadjah Mada. (1989).

29. Primudia, E. G., \& Kusnadi, J.: Aktivitas Antioksidan Minuman Probiotik Sari Kurma (Phoenix Dectilyfera L.) dengan Isolat L. Plantarum dan L. Casei. Jurnal Pangan dan Argoindustri. 2(3), 98-109 (2014).

30. Patty, C. N., Datulong, V., \& Suwetja, I. K.: Mutu Ikan Roa (Hemirhampus sp) Asap yang Ada di Pasar tradisional di Kota Manado yang Disimpan Pada Suhu Ruang. Jurnal Media teknologi Hasil Perikanan. 3(2), 45-54 (2015).

31. Ghasemi, K., Ghasemi, Y., Ebrahimzadeh, M. A.: Antioxidant activity, phenol and Flavonoid Contents of 13 Citrus species Peels and Tissues. Pakistan Journal of Pharmaceutical Sciences. 22(3), 227-281 (2009).

32. Sari, K. N.: Kandungan Serat, Vitamin C, Aktivitas Antioksidan dan Organoleptik Keripik Ampas Brokoli (brassica oleracea var italic) Panggang. Artikel Penelitian. (2014).

33. Cagno, R. D., Minervini, G., Rizzello, C. G., Angelis, M. D., Gobbetti, M.: Effect of lactic fermentation on antioxidant, texture colour and sensory properties of red green smoothies. 28,1062-1071 (2011).

34. Andres, V., Villanueva, M. J., Tenorio, M. D.: The effect of high- pressure processing on colour, bioactive compounds and antioxidant activity in smoothie during refrigerated storage. 192, 328-335 (2016).

35. Yulita, R., Purwijantiningsih, E., Sidharta, B. R.: Viabilitas Bakteri Asam Laktat dan Aktivitas Antimikroba Susu Fermentasi Terhadap Streptococcus pyogenes, Vibrio cholera dan Candida albicans. Jurnal Universitas Atma Jaya Yogyakarta. 1-14 (2014).

36. Nurhayati, Nelwida, \& Berliana.: Perubahan Kandungan Protein dan Serat Kasar Kulit Nanas yang Difermentasi dengan Plain Yoghurt. Jurnal Ilmiah Ilmu - Ilmu Peternakan. 17(1), 31-38 (2014).

37. Suryani, N., Bakhtiarsyah, A., \& Erianti, D.: Perbedaan Mutu (Karbohidrat, Serat dan Vitamin C) serta Daya Terima Jus Tomat (Lycopersicum esculentum var. grandifolium) Berkulit dan Tanpa Kulit yang Diolah Menggunakan Berbagai Alat Pengolahan Sebagai Minuman Alternatif Penderita Diabetes Melitus. Jurkessia. 6(3), 10-17 (2016).

38. Komalasari, N. N. T., Suter, I. K., \& Darmayanti, L. P. T.: Kajian Karakteristik Lawar Bonggol Pisang (Musa sp). Jurnal Ilmu dan Teknologi Pangan. 2-10 (2016).

39. Tiara.: Pengaruh Penambahan Ekstrak Daun Cincau Hijau Rambat Terhadap Kadar Serat, Viskositas, Total Koloni Bakteri Asam Laktat (BAL) dan Nilai Organoleptik Susu Permentasi. Fakultas Perternakan Universitas Andalas padang. (2016).

40. Antarini, A. A. N.: Sinbiotik antara prebiotik dan probiotik. Jurnal Ilmu Gizi. 2(2), 148-155 (2011).

41. Tampubolon, R. H. S. H., Yusmarini, \& Johan, V. S.: Penambahan Buah Nanas Dalam Pembuatan Velva Wortel. JOM FAPERTA. 4(2), 1-15 (2017). 
42. Haryati, L. F.: Aktivitas Antibakteri Berbagai Jenis Madu Terhadap Mikroba Pembusuk (Pseudomonas fluorescens FNCC 0071 dan Pseudomonas putida FNCC 0070). Skripsi Fakultas Pertanian Universitas Sebelas Maret. Surakarta. (2010).

43. Rahayunia, S., Mukarlina, Rusmiyanto, E.: Pengaruh Penambahan Sari Buah Lakum (Cayratia Trifolia (L) Domin) Terhadap kualitas dan Penerimaan Organoleptik pada yogurt. Jurnal Protobiont. 7(2), 1-9 (2018).

44. Zhu, B., Yang, J., He, Y., Zang, Y., \& Zhu, Z.: Glucosinolate Accumulation and Related Gene Expression in Pak Choi (Brassica rapa L. ssp. Chinensis var. Communis (N. tsen \& S.H. Lee) Hanelt) In Response to insecticide Application. Journal of Agricultural and Food Chemistry. 1-7 (2015).

45. Xionan, L., Wenxing, P., \& Piao, Zhongyun.: Omics Meets Phytonutrients in Vegetable Brassicas: for Nutritional Quality breeding. Horticultural Plant Journal. 1-17 (2017).

46. Wibowo, B. A., Rivai, M., \& Tasripan.: Alat Uji Kualitas Madu Menggunakan Polarimeter dan Sensor Warna. Jurnal Teknik ITS. 5(1), 28-33 (2016).

47. Sari, N. P., Leni, B., Roza, R. M.: Isolasi dan Karakteristik Bakteri Asam Laktat (BAL) Dari Buah- Buahan di Riau. Pekanbaru FMIPA UR. 1-11 (2013). 